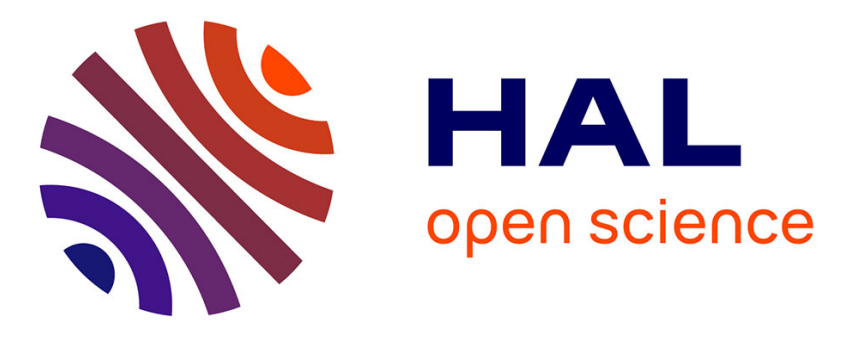

\title{
Simple high-performance liquid chromatographic method to analyse megazol in human and rat plasma
}

Bertin Enanga, Christian Labat, Hamid Boudra, G. Chauvière, M. Keita, B. Bouteille, Michel Dumas, Georges Houin

\section{- To cite this version:}

Bertin Enanga, Christian Labat, Hamid Boudra, G. Chauvière, M. Keita, et al.. Simple highperformance liquid chromatographic method to analyse megazol in human and rat plasma. Journal of Chromatography B - Analytical Technologies in the Biomedical and Life Sciences, 1997, 696 (2), pp.261-266. 10.1016/s0378-4347(97)00262-4 . hal-02696294

\section{HAL Id: hal-02696294 \\ https: / hal.inrae.fr/hal-02696294}

Submitted on 1 Jun 2020

HAL is a multi-disciplinary open access archive for the deposit and dissemination of scientific research documents, whether they are published or not. The documents may come from teaching and research institutions in France or abroad, or from public or private research centers.
L'archive ouverte pluridisciplinaire HAL, est destinée au dépôt et à la diffusion de documents scientifiques de niveau recherche, publiés ou non, émanant des établissements d'enseignement et de recherche français ou étrangers, des laboratoires publics ou privés. 


\title{
Simple high-performance liquid chromatographic method to analyse megazol in human and rat plasma
}

\author{
B. Enanga ${ }^{a, c}$, C. Labat $^{c}$, H. Boudra ${ }^{c}$, G. Chauvière ${ }^{b}$, M. Keita ${ }^{a}$, B. Bouteille ${ }^{a}$, \\ M. Dumas ${ }^{\mathrm{a}}$, G. Houin ${ }^{\mathrm{c}, *}$ \\ 'Institut d'Epidémiologie Neurologique et de Neurologie Tropicale, Faculté de Médecine, 2 Rue du Docteur Marcland, \\ F 87025 Limoges, France

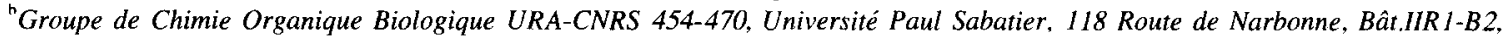 \\ F 31062 Toulouse. France \\ "Laboratoire de Cinétique des Xénobiotiques, Faculté des Sciences Pharmaceutiques, 35 Chemin des Maraîchers, F 31062 Toulouse, \\ France
}

Received 10 December 1996; received in revised form 18 April 1997; accepted 18 April 1997

\begin{abstract}
A simple and sensitive high-performance liquid chromatographic method has been developed to measure megazol in human plasma. The method was optimized and validated according to the Washington Concensus Conference on the Validation of Analytical Methods (V.P. Shah et al., Eur. J. Drug Metab. Pharmacokinet., 15 (1991) 249). The criteria of complete validation were specificity, linearity, precision, analytical recovery, dilution and stability. It involved extraction of the plasma with dichloromethane, followed by reversed-phase high-performance liquid chromatography using a Kromasil ${ }^{\mathbf{R}}$ $\mathrm{C}_{8}$ column and UV detection at $360 \mathrm{~nm}$. The retention times of the internal standard (tinidazol) and megazol were 6.10 and $9.60 \mathrm{~min}$, respectively. The standard curve was linear from $2 \mathrm{ng} \mathrm{ml}^{-1}$ (limit of quantification) to $2000 \mathrm{ng} \mathrm{ml}^{-1}$. The coefficients of variation for all the criteria of validation were less than $6 \% ; 85$ to $92 \%$ extraction efficiencies were obtained. Megazol was stable during the storage period (one month at $-20^{\circ} \mathrm{C}$ ) in plasma and for two months at $25^{\circ} \mathrm{C}$ in standard solution. The method was tested by measuring the plasma concentration following oral administration to rat and was shown to be suitable for pharmacokinetic studies. (C) 1997 Elsevier Science B.V.
\end{abstract}

Keywords: Megazol

\section{Introduction}

Megazol is a 5-nitroimidazole thiadiazole (Fig. 1) that was first synthesised in 1968 by Berkelhammer and Asato [1], who screened it for its efficacy against

* Corresponding author. protozoal infections in mice. Recently, Bouteille et al. [2] studied megazol activity against Trypanosoma brucei brucei infections in mice. In vitro, megazol exhibited a trypanocidal effect with an $\mathrm{MEC}_{100}$ (100\% minimal effective concentration) equal to 0.1 $\mu \mathrm{g} \mathrm{ml}^{-1}$, which is ten-times more effective than that of Suramin $\left(\mathrm{MEC}_{100}=1 \mu \mathrm{g} \mathrm{ml}{ }^{-1}\right.$ ). In vivo, a single $20 \mathrm{mg} \mathrm{kg}^{-1}$ injection of megazol cured mice of acute trypanosomal infection. For subacute infection with 


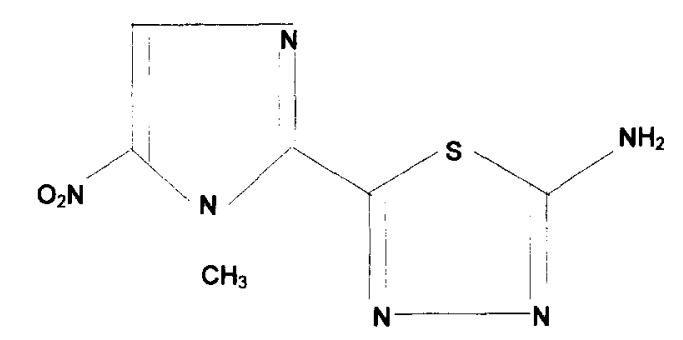

MEGAZOL

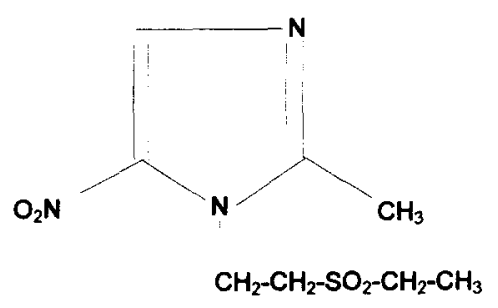

TINIDAZOL ( I.S.)

Fig. 1. Structures of megazol and tinidazol.

central nervous system involvement, megazol or Suramin administered alone did not show any effect on the progression of the disease. In contrast, their combined use proved to be extremely effective. It is not known if the trypanocidal effect is due to the parent compound or to one or more of its metabolites. Determination of megazol in biological fluids would clarify whether megazol crosses the bloodbrain barrier or not, and would allow pharmacokinetic studies to be carried out in vivo.

The purpose of this paper is to describe a complete optimised high-performance liquid chromatographic (HPLC) method and its full validation according to the Washington Conference Consensus on the Validation of Analytical Methods [3]. The quantification of megazol is validated in human plasma and has been applied to rat plasma.

\section{Experimental}

\subsection{Chemicals}

Megazol, 2-amino-5-[1-methyl-5-nitro-2-imidazolyl] 1,3,4 thiadiazole was synthesised by $G$.
Chauvière and tinidazol, used as the internal standard, was purchased from Sigma, France (ref. 32H0386).

\subsection{Reagents}

Chemicals were of analytical grade and human plasma was obtained from Institute Jacques Boy, France.

\subsection{Extraction procedure}

To $1 \mathrm{ml}$ of plasma, $50 \mu \mathrm{l}$ of the internal standard solution ( $10 \mu \mathrm{g} \mathrm{ml}^{-1}$ in mobile phase) and $50 \mu \mathrm{l}$ of $1 M$ sodium hydroxide were added in a $15-\mathrm{ml}$ conical polypropylene tube with $7 \mathrm{ml}$ of dichloromethane. The samples were mixed on a rotatory agitator for $20 \mathrm{~min}$, then centrifuged at $1636 \mathrm{~g}$ for $10 \mathrm{~min}$.

After centrifugation, the organic phase $(5 \mathrm{ml})$ was transferred to glass tubes and evaporated to dryness at $45^{\circ} \mathrm{C}$ under a stream of nitrogen. The dried residues were redissolved by vortex agitation in the mobile phase $(200 \mu \mathrm{l})$ and $50 \mu \mathrm{l}$ of the extract was injected onto the HPLC column.

\subsection{Chromatographic system}

The following modular HPLC system was used: a Model SP-8810 precision isocratic pump at 170 bar (Spectra Physics, Darmstadt, Germany), a Model Spectra chrom 100 UV monitor (Spectra Physics) fitted with a Model SP-8875 automatic sampler (Spectra Physics) and equipped with a 50- $\mu$ l loop. Data processing and calculations were carried out using a Chrom jet integrator (Spectra Physics) with the help of PCe software WINner/286 (Spectra Physics).

The Kromasil ${ }^{\mathrm{R}}$ column $(250 \times 4 \mathrm{~mm}$ I.D, $10 \mu \mathrm{m}$ particle size) was packed with $\mathrm{C}_{8}$ (Bischoff Chromatography, Leonberg, Germany). The mobile phase consisted of $0.068 M$ phosphate buffer, $\mathrm{pH} \mathrm{3}$, containing methanol and acetonitrile $(65: 20: 15, \mathrm{v} / \mathrm{v})$. The flow-rate was set at $0.7 \mathrm{ml} \mathrm{min}{ }^{-1}$ and UV detection was at $360 \mathrm{~nm}$. The system was used at room temperature. 


\subsection{Validation criteria}

\subsubsection{Specificity}

This criteria was validated on analysing human samples from six different subjects.

\subsubsection{Analytical recovery}

Analytical recovery was determined by comparing the peak areas of extracts to that obtained on direct injection of the same amount of megazol in mobile phase solution. The assay was determined at three concentrations, each of which was analysed in triplicate.

\subsubsection{Calibration curves}

Working standards were prepared in drug-free plasma $(900 \mu \mathrm{l})$ from the stock standard $(100 \mu \mathrm{l})$ to yield concentrations of $2,5,10,50,500,1000,1600$ and $2000 \mathrm{ng} \mathrm{ml}^{-1}$ (free-base) in plasma. Nine reference samples for calibration were included in the daily series of analysis. The calibration factors were calculated according to least-squares linear regression, weighted by $1 / C$.

\subsubsection{Intra- and inter-day variability}

These assays were determined by HPLC analysis of six quality control (QC) samples for each concentration $\left(5,110\right.$ and $\left.1400 \mathrm{ng} \mathrm{ml}^{-1}\right)$ during the same day (repeatability) and of two samples for each concentration on five consecutive days (reproducibility).

\subsubsection{Dilution}

The influence of dilution was studied on a blank plasma sample spiked to obtain a concentration that was two-fold higher than the maximal concentration of the calibration curve. It was then diluted to one third with the same plasma.

\subsubsection{Stability}

The stability of megazol in plasma was evaluated for one month at $-20^{\circ} \mathrm{C}$, and for three freeze-thaw cycles. The validation criteria were calculated using commonly accepted statistical procedures. The preci- sion and accuracy of each QC value should not have exceeded a deviation of $15 \%$, except for the QC samples near the limit of quantification (LOQ), where $20 \%$ was acceptable.

\subsubsection{Pharmacokinetics in rat}

Megazol concentrations in rat plasma were obtained after a single oral dose of $10 \mathrm{mg} \mathrm{kg}^{-1}$ over 24 h.

\section{Results and discussion}

\subsection{Specificity}

Fig. 2 illustrates representative chromatograms of a blank plasma and plasma spiked with $10 \mathrm{ng} \mathrm{ml}^{-1}$ of megazol and with $500 \mathrm{ng}$ of tinidazol. The two peaks were well separated, with retention times of 6.10 and $9.60 \mathrm{~min}$ for internal standard and megazol, respectively, using a mobile phase composed of phosphate buffer-methanol-acetonitrile. No peaks from endogenous compounds that interfered with megazol and tinidazol were observed with the six tested plasma samples.

\subsection{Extraction and recovery}

Since the evaporation time for a dichloromethane extract was significantly lower $(20 \mathrm{~min})$ and gave a very clean extract, this solvent was chosen. The analytical recoveries of megazol at 5, 110 and 1400 ng $\mathrm{ml}^{-1}$ were $90.8,92.2$ and $87.5 \%$, respectively $(n=3)$ for each concentration level. The recovery of internal standard was also good (93\%) at $2500 \mathrm{ng}$ $\mathrm{ml}^{-1}$.

\subsection{Linearity and sensitivity}

Excellent linearity was observed between the peak area ratios in plasma (megazol/tinidazol) and the theoretical concentrations $\left(r^{2}=0.999\right)$. The LOQ was $2 \mathrm{ng} \mathrm{ml}^{-1}$ in plasma. The calibration curve data obtained throughout the validation study are summa- 


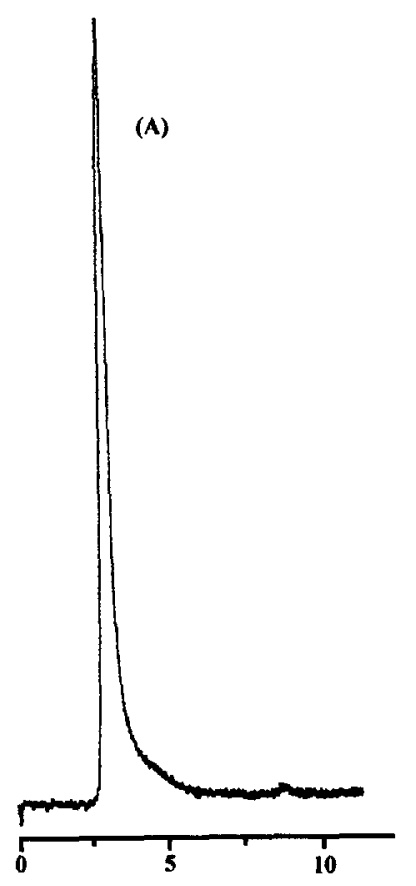

(B)

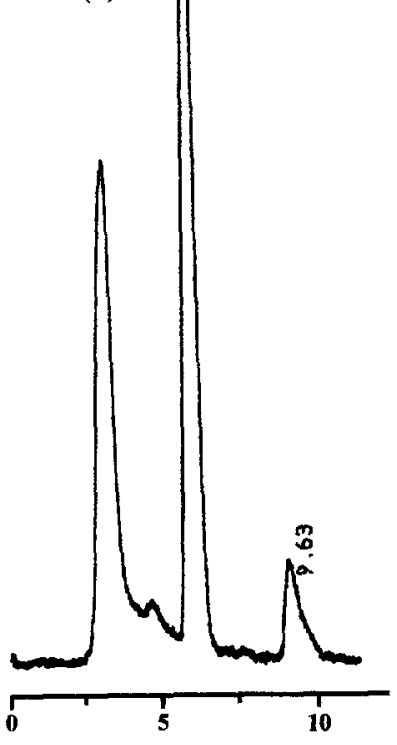

Fig. 2. Chromatograms of plasma extracts. (A) Blank human plasma, (B) human plasma spiked with $10 \mathrm{ng} / \mathrm{ml}$ of megazol and $500 \mathrm{ng}$ of tinidazol.

rised in Table 1. The day-to-day slope variability of the calibration curves was $0.57 \%(n=5)$.

\subsection{Influence of dilution}

The precision and accuracy of six replicates of diluted plasma were 2.8 and $99.4 \%$, respectively.

\subsection{Intra- and inter-day validation}

The within- and between-day variations of $\mathrm{QC}$ samples are given in Table 2. For each level, the repeatability and reproducibility criteria were clearly satisfactory. The accuracy for both assays (intra- and inter-day) was greater than $90 \%$ for all tested concentrations.

\subsection{Stability}

After four weeks of storage at $-20^{\circ} \mathrm{C}, \mathrm{QC}$ samples were shown to be stable at three concentrations (Table 3). No significant degradation of megazol was observed after three freeze-thaw cycles: 101 vs. 102 $\mathrm{ng} \mathrm{ml}{ }^{-1}$ and 1304 vs. $1332 \mathrm{ng} \mathrm{ml}^{-1}$. The standard solution of $50 \mathrm{ng} \mathrm{ml}^{-1}$ that was stored at room temperature was tested six times from the time of its preparation up to 25 days and the results indicate that the solution of megazol was stable. Also, the dry extract was shown to be stable at $4^{\circ} \mathrm{C}$ for $24 \mathrm{~h}$.

\subsection{Application}

Fig. 3 illustrates the plasma concentrations measured over $24 \mathrm{~h}$ after a single oral dose of $10 \mathrm{mg}$ 
Table 1

Calibration curve data (inter-assay precision)

\begin{tabular}{|c|c|c|c|c|c|c|c|c|}
\hline & \multicolumn{8}{|c|}{$C(\mathrm{ng} / \mathrm{ml})$} \\
\hline & 2 & 5 & 10 & 50 & 500 & 1000 & 1600 & 2000 \\
\hline Day 1 & 1.971 & 5.216 & 8.972 & 54.632 & 494.397 & 984.631 & 1594.293 & 2022.888 \\
\hline Day 2 & 2.225 & 5.084 & 9.466 & 47.091 & 482.019 & 1011.481 & 1617.539 & 1992.096 \\
\hline Day 3 & 1.868 & 4.818 & 10.737 & 53.162 & 482.231 & 984.086 & 1613.285 & 2016.813 \\
\hline Day 4 & 1.996 & 5.302 & 9.775 & 48.602 & 487.544 & 1017.935 & 1608.090 & 1987.757 \\
\hline Day 5 & 2.155 & 4.496 & 9.625 & 53.353 & 497.733 & 992.025 & 1620.301 & 1987.313 \\
\hline Mean & 2.04 & 4.98 & 9.71 & 51.37 & 488.8 & 998.0 & 1610.7 & 2001.4 \\
\hline S.D. & 0.14 & 0.33 & 0.65 & 3.31 & 7.10 & 15.71 & 10.27 & 17.11 \\
\hline $\mathrm{CV} \%$ & 7.07 & 6.59 & 6.65 & 6.44 & 1.45 & 1.57 & 0.64 & 0.85 \\
\hline Accuracy $\%$ & 97.84 & 99.66 & 97.15 & 97.26 & 97.76 & 99.8 & 99.33 & 99.93 \\
\hline
\end{tabular}

Table 2

Analysis precision of quality control samples

\begin{tabular}{|c|c|c|c|c|c|c|c|}
\hline \multicolumn{4}{|c|}{ Inter-day precision } & \multicolumn{4}{|c|}{ Intra-day precision } \\
\hline & QC1 & QC2 & QC3 & & QC1 & $\mathrm{QC} 2$ & QC3 \\
\hline & 5 & 110 & 1400 & & 5 & 110 & 1400 \\
\hline & 5.5 & 119 & 1410.4 & & 5 & 112.1 & 1295.5 \\
\hline & 5.5 & 126.2 & 1440.2 & & 4.7 & 119.8 & 1352.5 \\
\hline & 4.1 & 112.1 & 1371.9 & & 4.1 & 109 & 1371.9 \\
\hline & 4.7 & 119.8 & 1366.6 & & 5.2 & 97.7 & 1366.6 \\
\hline & 3.2 & 118.8 & 1396.1 & & 5.3 & 109.8 & 1396.5 \\
\hline & 4.2 & 119 & 1370.7 & & 5.1 & 102.5 & 1302.8 \\
\hline & 3.9 & 128.6 & 1396 & & & & \\
\hline & 4.9 & 111.3 & 1420.4 & Mean & 4.90 & 108.5 & 1347.6 \\
\hline & 4.6 & 120.5 & 1390.5 & S.D. & 0.40 & 7.70 & 40.2 \\
\hline & 4.3 & 114.6 & 1362.8 & C.V. $(\%)$ & 8.90 & 7.10 & 3.00 \\
\hline & & & & Accuracy $(\%)$ & 98.00 & 98.60 & 96.30 \\
\hline Mean & 4.50 & 119.00 & 1392.60 & & & & \\
\hline S.D. & 0.70 & 5.50 & 25.50 & & & & \\
\hline C.V. $(\%)$ & 16.00 & 4.60 & 1.80 & & & & \\
\hline Accuracy (\%) & 89.60 & 91.80 & 99.50 & & & & \\
\hline
\end{tabular}

Table 3

Stability of megazol in human plasma at $-20^{\circ} \mathrm{C}$

\begin{tabular}{lccc}
\hline & QC 1 & QC 2 & QC 3 \\
\hline & 4.600 & 121.7 & 1365.80 \\
& 4.000 & 107.5 & 1445.40 \\
& 3.500 & 120.3 & 1411.2 \\
& 3.900 & 110.9 & 1442.8 \\
& 3.800 & 116 & 1297.8 \\
& 3.000 & 118.8 & 1405.30 \\
Mean & 3.800 & 115.9 & 1399.70 \\
S.D. & 0.500 & 5.6 & 58.70 \\
C.V. (\%) & 14.20 & 4.80 & 4.20 \\
Accuracy (\%) & 75.90 & 94.70 & 99.90 \\
\hline
\end{tabular}

$\mathrm{kg}^{-1}$ megazol in rats. Each value corresponds to the mean of three samples. This figure shows that the technique is suitable for pharmacokinetic studies of megazol.

\section{Acknowledgments}

This work received the financial support of Ministère Français de la Coopération (Programme Mobilisateur Trypanosomiase, Projet TR-9603). The 


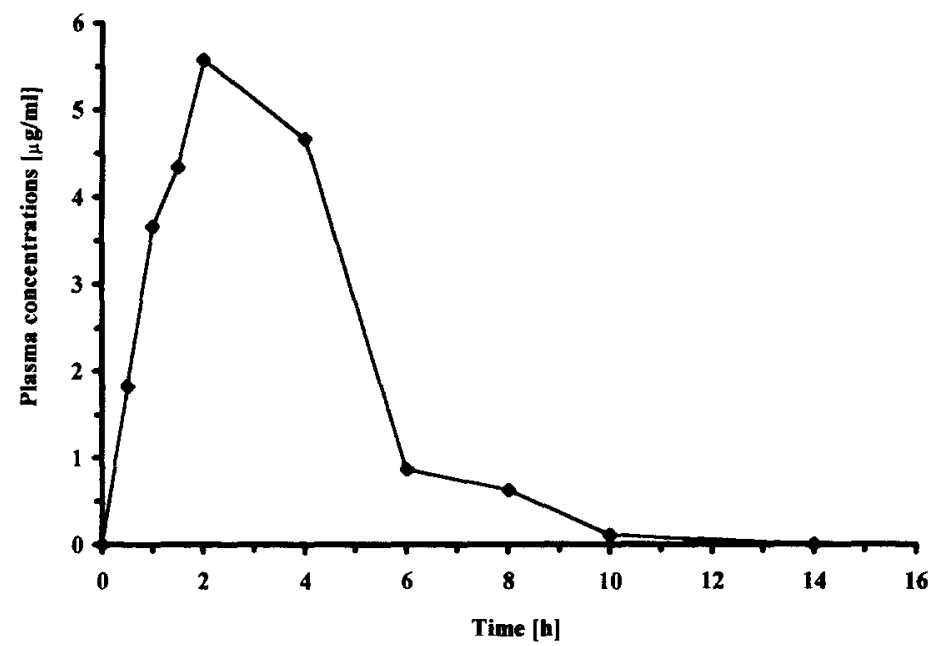

Fig. 3. Plasma concentrations versus time profile of megazol.

help of John Woodley in the preparation of the manuscript was gratefully acknowledged.

\section{References}

[1] G. Berkelhammer, G. Asato, Science 162 (1968) 1146.

[2] B. Bouteille, A. Marie-Daragon, G. Chauvière, C. De Albuquerque, B. Enanga, M.L. Dardé, J.M. Vallat, J. Périé, M. Dumas, Acta Trop. 60 (1995) 73 .
[3] V.P. Shah, K.K. Midha, S. Dighe, I.J. McGilveray, J.P. Skelly, A. Yacobi, T. Layloff, C.T. Viswanathan, C.E. Cook, R.D. McDowall, K.A. Pittman, S. Spector, Eur. J. Drug Metab. Pharmacokinet. 16 (1991) 249. 